\title{
Hepatitis B virus $X$ protein promotes liver cell proliferation via a positive cascade loop involving arachidonic acid metabolism and p-ERK1/2
}

Changliang Shan ${ }^{1}$, Fuqing Xu ${ }^{1}$, Shuai Zhang ${ }^{1}$, Jiacong You $^{2}$, Xiaona You ${ }^{1}$, Liyan Qiu ${ }^{1}$, Jie Zheng ${ }^{2}$, Lihong Ye $^{2}$, Xiaodong Zhang ${ }^{1}$

${ }^{I}$ Department of Cancer Research, Key Laboratory of Molecular Microbiology and Technology, Ministry of Education, Institute For Molecular Biology, College of Life Sciences, Nankai University, Tianjin 300071, China, '²Department of Biochemistry, The Key Laboratory of Bioactive Materials, Ministry of Education, College of Life Sciences, Nankai University, Tianjin 300071, China

Hepatitis B virus $\mathrm{X}$ protein (HBx) plays a crucial role in the development of hepatocellular carcinoma. Here, we sought to identify the mechanisms by which $\mathrm{HBx}$ mediates liver cell proliferation. We found that HBx upregulated the levels of cyclooxygenase-2 (COX-2), 5-lipoxygenase (5-LOX) and phosphorylated extracellular signal-regulated protein kinases 1/2 (p-ERK1/2) in liver cells. HBx-induced p-ERK1/2 was abolished by inhibition of Gi/o proteins, COX or LOX. In addition, HBx increased the amounts of prostaglandin E2 (PGE2) and leukotriene B4 (LTB4) released from cell lines derived from hepatocytes. Moreover, these released arachidonic acid metabolites were able to activate ERK1/2. Interestingly, activated ERK1/2 could upregulate the expression of COX-2 and 5-LOX in a positive feedback manner. In conclusion, HBx enhances and maintains liver cell proliferation via a positive feedback loop involving COX-2, 5-LOX, released arachidonic acid metabolites, Gi/o proteins and p-ERK1/2.

Keywords: hepatitis B virus X protein, proliferation, signal pathway, arachidonic acid metabolites, ERK

Cell Research (2010) 20:563-575. doi:10.1038/cr.2010.49; published online 13 April 2010

\section{Introduction}

More than 350 million people worldwide are infected with the hepatitis B virus (HBV), some of whom have developed hepatitis, cirrhosis and hepatocellular carci-

Correspondence: Xiaodong Zhang ${ }^{\mathrm{a}}$, Lihong $\mathrm{Ye}^{\mathrm{b}}$

${ }^{\mathrm{a}}$ Tel: +86-22-23506830; Fax: +86-22-23501385

E-mail: zhangxd@nankai.edu.cn

${ }^{\mathrm{b}}$ Tel: +86-22-23501385; Fax: +86-22-23501385

E-mail: yelihong@nankai.edu.cn

Abbreviations: HBV (hepatitis B virus); $\mathrm{HBx}$ (hepatitis B virus X protein); HCC (hepatocellular carcinoma); COX-2 (cyclooxygenase-2); 5-LOX (5-lipoxygenase); ELISA (enzyme-linked immunosorbent assay); PGE2 (prostaglandin 2); LTB4 (leukotriene B4); JAK (Janus kinase); STAT (activator transcription factor); MAPK (Ras/Raf-mitogen-activated protein kinase); ERK (extracellular signal-regulated protein kinase); p-ERK1/2 (phosphorylated ERK1/2); LTs (leukotrienes); PG (prostaglandin); PTX (pertussis toxin); indo (indomethacin); BrdU (5'-bromodeoxyuridine); RTPCR (reverse transcription-polymerase chain reaction); RTKs (receptor tyrosine kinases); GPCR (G-protein-coupled receptor)

Received 9 Octorber 2009; revised 10 December 2009; accepted 30 December 2009, published online 13 April 2010 noma (HCC) $[1,2]$ as a result. Many studies suggest that the HBV X protein (HBx), encoded by the $X$ gene, has a crucial role in the development of HCC [3]. HBx can also affect transcription, cell growth and apoptosis [4]. $\mathrm{HBx}$ is a transcriptional activator that can interact with a wide variety of regulatory elements, such as AP-1, AP-2, $\mathrm{NF}-\kappa \mathrm{B}$ and $\mathrm{cAMP}$ response element binding. Cytosolic $\mathrm{HBx}$ also participates in a wide range of signal transduction pathways (for example, the Akt, Wnt/ $\beta$-catenin, $\mathrm{NF}-\kappa \mathrm{B}$, Janus kinase/signal transducer and activator transcription factor (JAK/STAT) and Ras/Raf-mitogenactivated protein kinase (MAPK) pathways) [5-8].

The MAPK family includes three distinct subfamilies: the extracellular signal-regulated protein kinases (ERKs), including ERK1 and ERK2, the stress-activated c-Jun N-terminal kinases and p38 kinase [9]. Activation of the MAPK cascade is necessary for cell growth and proliferation [10]. The MAPK family serves as a convergence point for intracellular signal transduction pathways (including coupling HBx cytoplasmic signaling to its gene expression program) and functions as a mediator of cel- 
lular responses to a variety of cellular stimuli $[11,12]$. Constitutively active mutations in this pathway increase kinase activity and can lead to transformation [12]. It has been reported that NF- $\mathrm{kB}$ and $\mathrm{AP}-1$ are downstream effectors of MAPK $[13,14]$, and phosphorylated ERK1/2 (p-ERK1/2) is clearly upregulated by HBx in cancer tissues [7].

Arachidonic acid (AA) is an important component of membrane phospholipids and can be liberated by phospholipase A2 (PLA2) activation. Three key classes of enzymes, cyclooxygenases (COX), lipoxygenases (LOX) and CPY450, can metabolize AA to produce biologically active eicosanoids, such as prostaglandins (PGs), thromboxanes, leukotrienes (LTs), hydroxyeicosatetraenoic acids and hydroperoxyeicosatetraenoic acids. These eicosanoids have a significant role in cancer cell growth [1517]. The key enzymes cyclooxygenase-2 (COX-2) and 5-lipoxygenase (5-LOX), which catalyze AA metabolism, are overexpressed during inflammation and multistage tumor progression in many neoplastic disorders, including lung, breast and pancreatic cancers. In HBVinfected HCC tissues, the $H B x$ gene is responsible for the upregulation of COX-2 [18-20]. We have found that $\mathrm{HBx}$ was able to regulate many genes associated with signal transduction pathways, cell cycle, metabolism and proliferation, and this regulation may be involved in the carcinogenesis associated with HBV [21]. Furthermore, in certain contexts, stable HBx transfection resulted in a malignant phenotype in human liver $\mathrm{L}-\mathrm{O} 2$ cells in vivo and in vitro [22].

It has been reported that $\mathrm{AA}$ metabolites are involved in the regulation of numerous signaling pathways. However, whether they play a role in HBx-mediated proliferation remains unclear. We hypothesized that AA metabolism and p-ERK1/2 may contribute to HBx-mediated cell proliferation. Our findings here show that $\mathrm{HBx}$ enhances and maintains the proliferation of liver cells via a positive cascade loop involving AA metabolism and p-ERK1/2.

\section{Results}

\section{HBx upregulates $p$-ERK1/2, COX-2 and 5-LOX}

We evaluated the phosphorylation levels of MAPK family proteins (phospho-ERK1/2, phospho-p38 and phospho-JNK) and the expression levels of enzymes associated with AA metabolism in the liver cell line, L-O2, and the hepatoma cell line, H7402. To assess the role of HBx, we used cells that had been stably transfected with a plasmid containing the gene for HBx (L-O2-X and H7402-X) or with a control vector (L-O2-pcDNA3 and H7402-P). Western blot analysis showed that the level of p-ERK1/2 was significantly increased in L-O2-X cells relative to L-O2 or L-O2-pcDNA3 cells (Figure 1), but the levels of p-p38 and p-JNK (Thr183 and Tyr185) in L-O2-X cells were no different from those in control cells (Supplementary information, Figure S1A). The levels of total ERK1/2, p38 and JNK were equivalent in L-O2-X and L-O2 cells or L-O2-pcDNA3 cells (Figure 1; Supplementary information, Figure S1A). We observed the same results in the hepatoma cell line expressing HBx, H7402-X (Figure 1; Supplementary information,

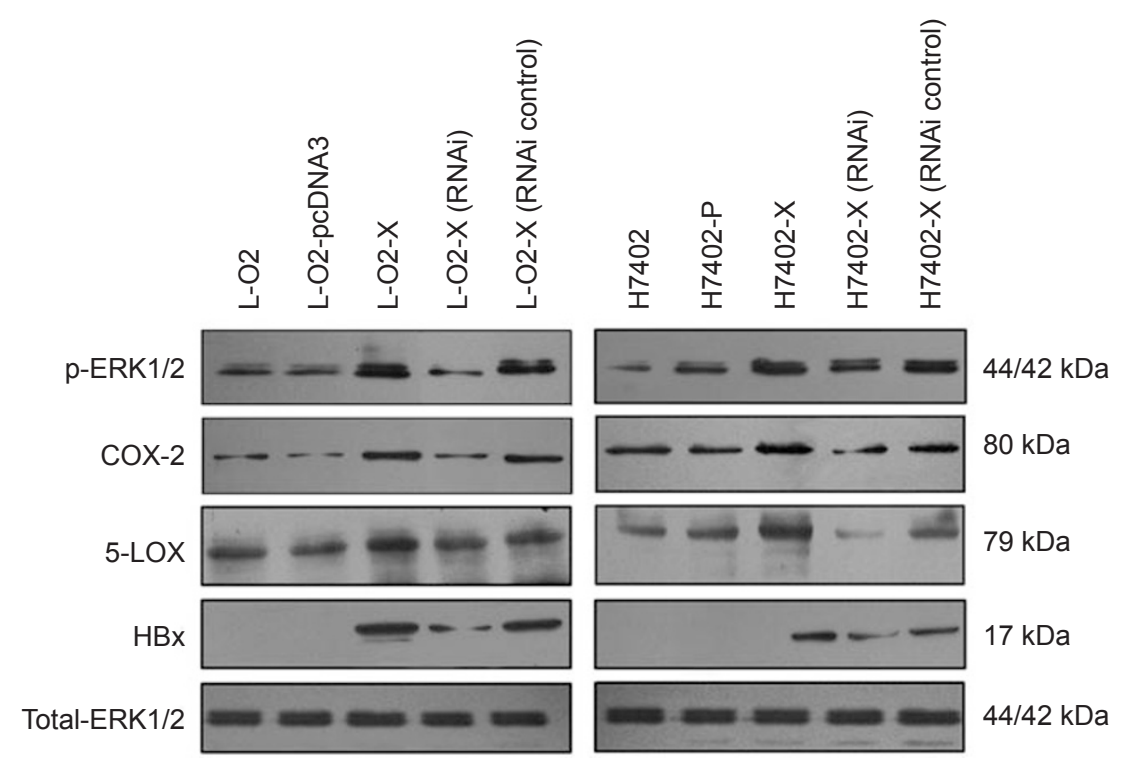

Figure $1 \mathrm{HBx}$ upregulates p-ERK1/2, COX-2 and 5-LOX. Western blot analysis showed that HBx upregulated levels of COX2 and 5-LOX as well as the expression of p-ERK1/2 in L-O2-X (or H7402-X) cells. RNAi targeting of HBx mRNA abolished this effect. 
Figure S1A). Western blot analysis also showed that the expression levels of COX-2 and 5-LOX were higher in $\mathrm{L}-\mathrm{O} 2-\mathrm{X}$ cells than those in $\mathrm{L}-\mathrm{O} 2$ and L-O2-pcDNA3 cells (Figure 1). Again, similar results were observed in the hepatoma H7402-X cells (Figure 1). The protein expression levels of COX-1 and 12R-LOX in L-O2-X cells were similar to those in L-O2 and L-O2-pcDNA3 cells (data not shown). Downregulation of HBx by RNAi abolished the upregulation of p-ERK1/2, COX-2 and 5-LOX, but a control RNAi did not (Figure 1). These data further suggest that HBx is responsible for the upregulation of $\mathrm{p}$-ERK1/2, COX-2 and 5-LOX.

\section{COX and LOX contribute to the activation of ERK1/2}

The ERK signaling cascade can be activated by a wide variety of receptors, including receptor tyrosine kinases (RTKs), G-protein-coupled receptors (GPCRs) and ion channels $[23,24]$. Many studies have revealed that $p$ ERK $1 / 2$ can be activated by the Gi/o family of GPCRs [25-27]. AA metabolite release is a receptor-dependent event, requiring a transducing $\mathrm{Gi} / \mathrm{o}$ protein to initiate phospholipid hydrolysis and release AA into the cytosol. To determine whether AA metabolites and Gi/o proteins are responsible for the activation of $\mathrm{p}$-ERK $1 / 2$ cascades in HBx-expressing liver (or hepatoma) cells, we added inhibitors of COX (indomethacin, indo), LOX (NDGA) and Gi/o proteins (pertussis toxin, PTX) to L-O2-X cells. To rule out any cytotoxic effects mediated by these inhibitors, we performed a nitro blue tertrazolium (NBT) assay. None of the inhibitors used in our experiments, PTX, indo, NDGA and PD98059, demonstrated cytotoxicity at the doses used (Supplementary information, Figure S1B), and they did not affect the expression levels of HBx, p-p38 and p-JNK in L-O2-X cells (Supplementary information, Figure S1C). We found that PTX, indo and NDGA significantly attenuated the level of $p$-ERK $1 / 2$ in L-O2-X cells in a dose- and time-dependent manner, but the levels of total ERK1/2 were not changed (Figure 2A).

Next, we examined whether the HBx-mediated release of AA metabolites could affect liver cells by treating $\mathrm{L}-\mathrm{O} 2$ cells with $\mathrm{L}-\mathrm{O} 2-\mathrm{X}$ conditioned media (L-O2-X $\mathrm{CM}$ ). Western blot analysis showed that both boiled and non-boiled L-O2-X CM strongly induced phosphorylation of ERK1/2 in L-O2 cells in a dose-dependent manner (Figure 2B). Boiling the media ruled out the possibility that proteins in the conditioned media have a role in the upregulation of p-ERK1/2. Control L-O2 CM did not alter the level of p-ERK1/2 in L-O2 cells (Supplementary information, Figure S1D). Moreover, the upregulation of $\mathrm{p}-\mathrm{ERK} 1 / 2$ in L-O2 cells in response to the L-O2-X CM
A
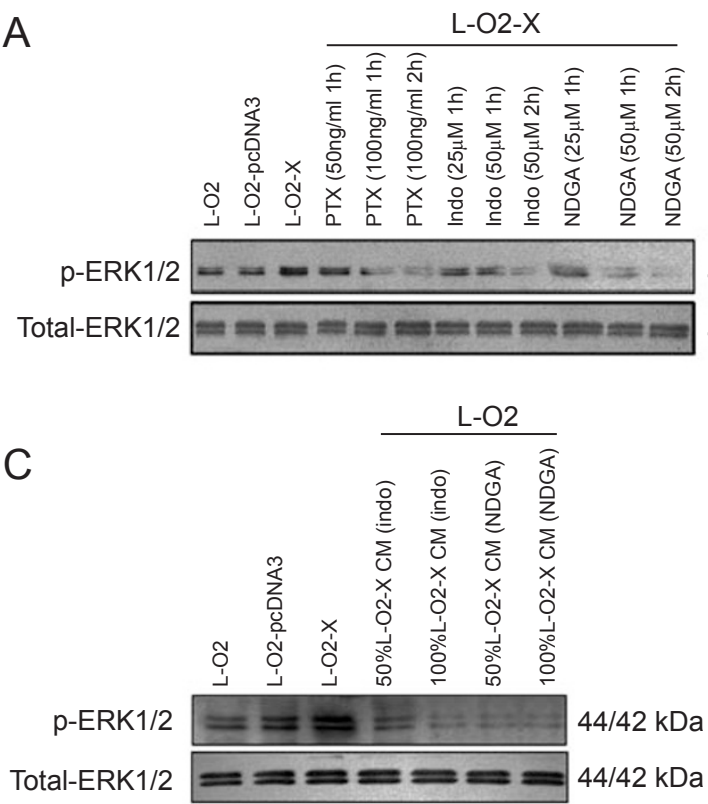
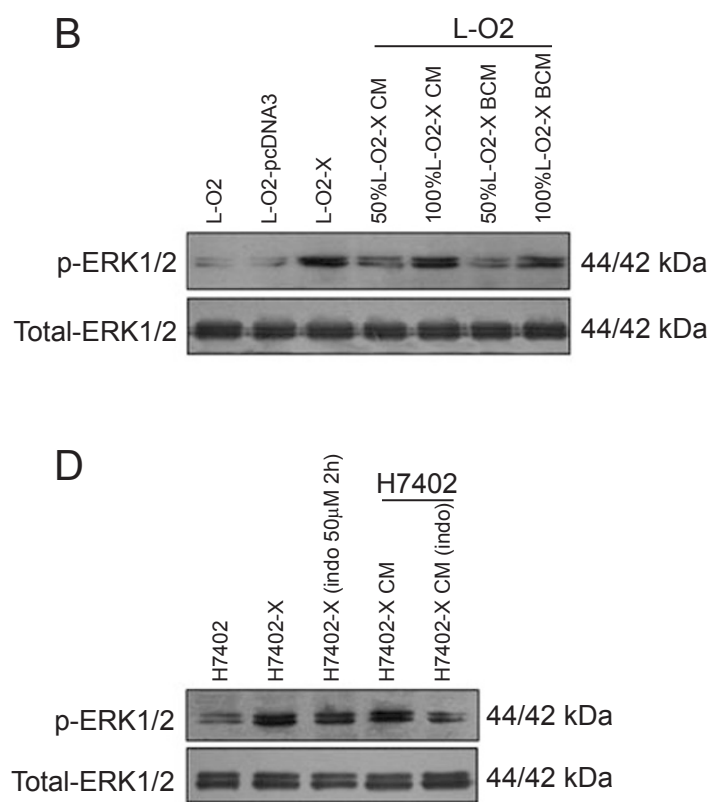

Figure $2 \mathrm{Gi} / \mathrm{o}$ proteins, COX and LOX are upstream activators of ERK1/2. (A) Western blot analysis showed that pertussis toxin (PTX, an inhibitor of Gi/o proteins), indomethacin (indo, an inhibitor of COX) and NDGA (an inhibitor of LOX) were all able to downregulate the level of p-ERK1/2 in L-O2-X cells. (B) Conditioned medium from L-O2-X cells (L-O2-X CM) or boiled conditioned medium from L-O2-X cells (L-O2-X BCM) activate ERK1/2 in L-O2 cells in a dose-dependent manner, as shown by western blot analysis. (C) In L-O2 cells, the activation of ERK1/2 mediated by L-O2-X-CM was abolished by pretreatment with indo or NGDA in a dose-dependent manner. (D) Similar results as in (A, B and C) are shown in H7402-X cells. 
A

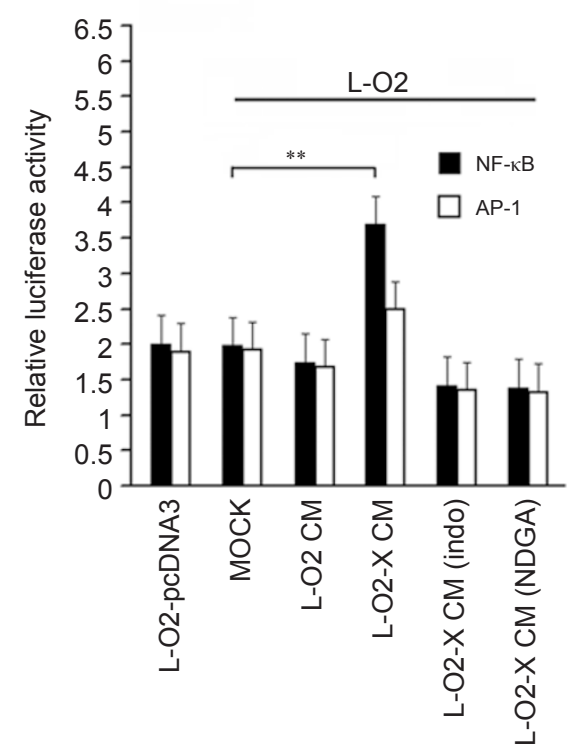

B

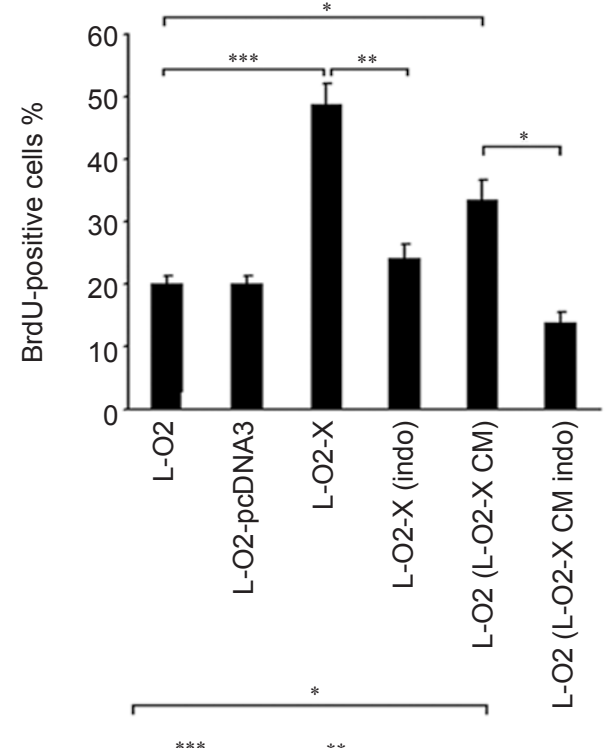

C

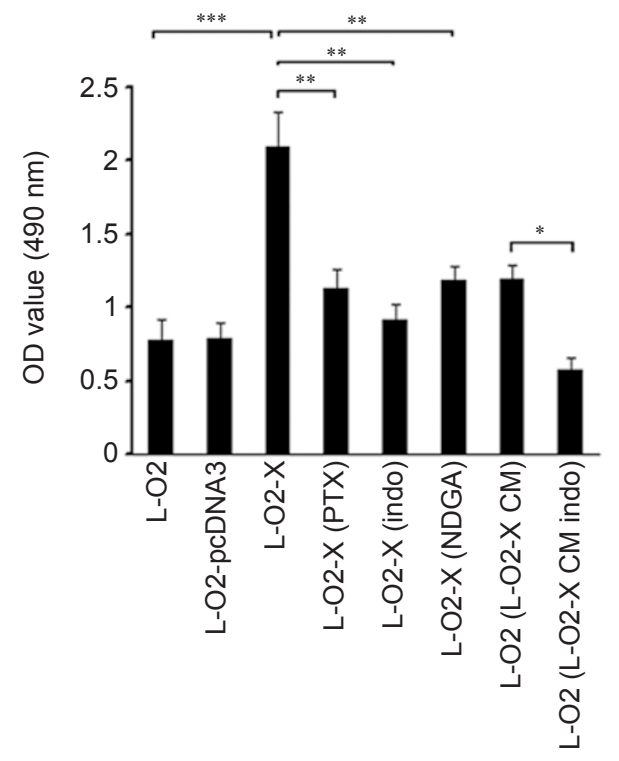

H7402
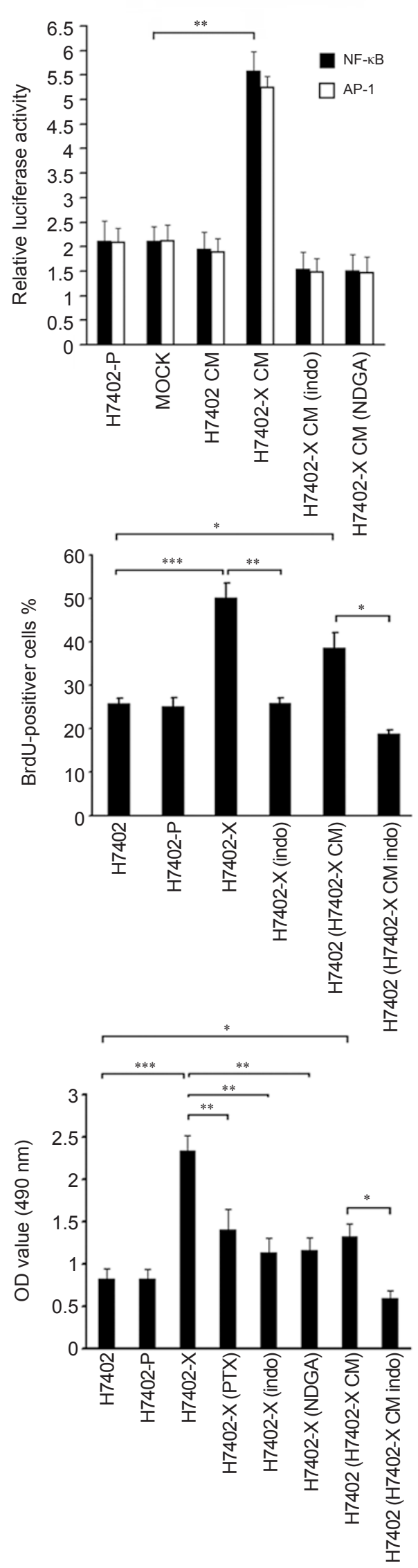

Cell Research | Vol 20 No 5 | May 2010 
was inhibited in a dose-dependent manner by pretreatment of the L-O2-X cells with indo or NDGA (Figure 2C). Similar results were observed in the $\mathrm{H} 7402$ cell line using western blot analysis (Figure 2D). These results suggest that the release of AA metabolites mediated by $\mathrm{HBx}$ is responsible for the activation of ERK $1 / 2$ and that AA metabolism by COX and LOX is critical for this process. We conclude that $\mathrm{HBX}$-mediated release of AA metabolites has an important role in the activation of ERK1/2 in liver cells.

Previous studies have shown that NF- $\mathrm{KB}$ and AP-1 are downstream effectors of ERK $[13,14]$. To provide further evidence that AA metabolites are responsible for the activation of ERK1/2, we investigated the effects of $\mathrm{L}-\mathrm{O} 2-\mathrm{X} \mathrm{CM}$ on the transcriptional activities of NF- $\mathrm{BB}$ and AP-1 in L-O2 cells using a reporter gene assay. The results of this assay showed that the L-O2-X CM was able to enhance the transcriptional activities of NF- $\kappa B$ $(* * P=0.000777$, vs $\mathrm{CM}$ from mock or L-O2-pcDNA3 cells, Student's $t$-test) and AP-1 (**P=0.008134, vs CM from mock or L-O2-pcDNA3 cells, Student's $t$-test). By contrast, L-O2 CM failed to enhance the transcriptional activities of NF- $\kappa \mathrm{B}$ and AP-1. L-O2-X CM from cells pretreated with indo or NDGA (abbreviated as L-O2-X $\mathrm{CM}$ (indo) and L-O2-X CM (NDGA)) also did not enhance NF- $\kappa$ B or AP-1 activity (Figure $3 \mathrm{~A}$ ). Similar results were found using the hepatoma $\mathrm{H} 7402$ and H7402-X cells (Figure 3A).

A 5'-bromodeoxyuridine (BrdU) incorporation assay showed that the proliferation of L-O2-X cells was elevated relative to L-O2 cells $(* * * P=0.00067$, Student's $t$-test), but this effect was abolished by pretreatment with $50 \mu \mathrm{M}$ indo for $2 \mathrm{~h}(* * P=0.008052$, vs untreated L-O2-X cells, Student's $t$-test). In addition, $\mathrm{L}-\mathrm{O} 2-\mathrm{X}$ CM promoted the growth of $\mathrm{L}-\mathrm{O} 2$ cells $(* P=$ 0.044641 , vs L-O2 cells, Student's $t$-test), but L-O2-X $\mathrm{CM}$ (indo) did not ( ${ }^{*} P=0.03303$, vs L-O2-X CM, Student's $t$-test). Similar results were obtained using
H7402 and H7402-X cells (Figure 3B). Cell proliferation was also assessed using a 3-(4,5-dimethylthiazol-2-yl)2,5-diphenyltetrazolium bromide (MTT) assay. The MTT assay showed that the proliferation of L-O2-X cells was elevated relative to L-O2 cells $(* * * P=0.00248$, Student's $t$-test), but this effect was abolished by pretreatment with $100 \mathrm{ng} / \mathrm{ml}$ PTX, $50 \mu \mathrm{M}$ indo or $50 \mu \mathrm{M}$ NDGA for $2 \mathrm{~h}$ (PTX: $* * P=0.014652$; indo: ${ }^{*} P=0.0180272$; NDGA: $* * P=0.018471$, vs untreated L-O2-X cells, Student's $t$-test). In addition, L-O2-X CM promoted the growth of L-O2 cells ( $* P=0.048252$, vs L-O2, Student's $t$-test), but L-O2-X CM (indo) did not $(* P=0.04171$, vs L-O2-X CM, Student's $t$-test). Similar results were obtained using H7402 and H7402-X cells (Figure 3C). Cell proliferation was also evaluated by flow cytometric analysis of the proportion of cells entering $\mathrm{S}$ phase (proliferation index (PI): $P<0.01$, Student's $t$-test, Tables 1 and 2; Supplementary information, Figure S2). The data above suggest that COX-2 and 5-LOX are responsible for promoting the proliferation of L-O2-X (or H7402-X) cells.

\section{Increased release of PGE2 and leukotriene B4 (LTB4) by $H B x$}

To provide further support for the roles of AA metabolites in the activation of ERK1/2, we determined the amounts of PGE2 (a metabolite of COX-2) and LTB4 (a metabolite of 5-LOX) in the conditioned media of L-O2, L-O2-X, H7402 and H7402-X cells by enzyme-linked immunosorbent assay (ELISA). The amounts of PGE2 and LTB4 were higher in the conditioned media of L-O2$X$ cells than those in the conditioned media of $\mathrm{L}-\mathrm{O} 2$ cells (PGE2: $* P=0.014277$, LTB4: $* P=0.013927$, vs L-O2 cells, Student's $t$-test). However, this elevation was abolished by pretreatment with indo or NDGA (PGE2: $* P=$ 0.046421; LTB4: ${ }^{*} P=0.040811$, vs untreated L-O2-X cells, Student's $t$-test). The amounts of PGE2 and LTB4 in the medium of L-O2 cells were also reduced when cells were treated with indo or NDGA. In addition, the

Figure 3 Released arachidonic acid metabolites contribute to the activation of ERK1/2 and promote cell growth. (A) A luciferase reporter gene assay showed that L-O2-X CM enhanced the transcriptional activities of NF- $\mathrm{KB}$ and AP-1 in L-O2 cells $(P<0.01$, Student's $t$-test). Conditioned media from L-O2-X cells pretreated with $50 \mu \mathrm{M}$ indo or $50 \mu \mathrm{M}$ NDGA for $2 \mathrm{~h}$ (L-O2-X CM (indo or NDGA)) lost this activity $(P<0.01$, Student's $t$-test). The same results were found in $\mathrm{H} 7402-\mathrm{X}$ cells. Data shown are from three independent experiments; error bars represent standard error of the mean or SEM. (B) BrdU incorporation assay showed that the proliferation of L-O2-X cells was greater than that of L-O2 cells $(P<0.01$, Student's $t$-test). This was abolished by pretreatment with $50 \mu \mathrm{M}$ indo for $2 \mathrm{~h}(P<0.01$, Student's $t$-test). L-O2-X CM promoted the growth of L-O2 cells $(P<0.05$, Student's $t$-test), but conditioned medium from L-O2-X cells pretreated with $50 \mu \mathrm{M}$ indo for $2 \mathrm{~h}$ (L-O2-X CM (indo)) did not $(P<0.05$, Student's $t$-test). Similar results were obtained in H7402-X and H7402 cells. (C) MTT assay showed that the proliferation of L-O2-X cells was greater than that of L-O2 cells $(P<0.01$, Student's $t$-test). This could be abolished by pretreatment with $100 \mathrm{ng} / \mathrm{ml}$ PTX, $50 \mu \mathrm{M}$ indo or $50 \mu \mathrm{M}$ NDGA for $2 \mathrm{~h}(P<0.05$, Student's $t$-test). L-O2-X CM promoted the growth of L-O2 cells $(P<0.05$, Student's $t$-test), but conditioned media from L-O2-X cells pretreated with $50 \mu \mathrm{M}$ indo for $2 \mathrm{~h}$ (L-O2-X CM (indo)) did not $(P<0.05$, Student's $t$-test). Similar results were obtained in $\mathrm{H} 7402$ and $\mathrm{H} 7402-\mathrm{X}$ cells. 
Table 1 Determination of proliferation index (PI) by flow cytometry analysis

\begin{tabular}{llllll}
\hline & L-O2 $(\%)$ & L-O2-X $(\%)$ & L-O2-X(indo $)(\%)$ & L-O2(L-O2-X CM $)(\%)$ & L-O2(L-O2-X CM indo) $(\%)$ \\
\hline Cell cycle G1 & 64.67 & 49.36 & 64.06 & 56.40 & 66.03 \\
Cell cycle G2 & 9.52 & 18.07 & 12.62 & 14.26 & 9.98 \\
Cell cycle S & 25.81 & 32.57 & 23.32 & 29.34 & 23.99 \\
PI & 35.33 & $* * 50.64$ & 35.94 & $* * 43.60$ & 33.97 \\
\hline
\end{tabular}

$\mathrm{PI}=[(\mathrm{S}+\mathrm{G} 2 / \mathrm{M}) /(\mathrm{G} 0 / \mathrm{G} 1+\mathrm{S}+\mathrm{G} 2 / \mathrm{M})] \times 100 . * * P<0.01, \mathrm{vs}$ L-O2 cells, Student's $t$-test.

Table 2 Determination of proliferation index (PI) by flow cytometry analysis

\begin{tabular}{llllll}
\hline & H7402(\%) & H7402-X(\%) & H7402-X(indo)(\%) & H7402(H7402-X CM)(\%) & H7402(H7402-X CM indo)(\%) \\
\hline Cell cycle G1 & 64.56 & 46.62 & 63.99 & 47.31 & 68.99 \\
Cell cycle G2 & 14.21 & 22.47 & 12.79 & 21.96 & 8.06 \\
Cell cycle S & 21.23 & 30.91 & 23.22 & 30.73 & 22.95 \\
PI & 35.44 & $* * 53.38$ & 36.01 & $* * 52.69$ & 31.01 \\
\hline
\end{tabular}

$\mathrm{PI}=[(\mathrm{S}+\mathrm{G} 2 / \mathrm{M}) /(\mathrm{G} 0 / \mathrm{G} 1+\mathrm{S}+\mathrm{G} 2 / \mathrm{M})] \times 100 . * * P<0.01$, vs H7402 cells, Student's $t$-test.

downregulation of HBx by RNAi abolished the increased levels of PGE2 and LTB4 in L-O2-X medium (PGE2: * $P$ $=0.048632$; LTB4: $* * P=0.045712$, vs untreated L-O2$X$ cells, Student's $t$-test; Figure 4A). Similar results were obtained using the hepatoma H7402 and H7402-X cells $(P<0.05$, Student's $t$-test; Figure 4B). Thus, our data support that released AA metabolites contribute to the activation of ERK1/2.

Upregulation of COX-2/5-LOX by exogenous $A A$ and their roles in ERK1/2 activation

To further verify that COX-2 and 5-LOX were responsible for the activation of ERK1/2, we added exogenous AA to L-O2 (or H7402) cells. The addition of AA upregulated the expression levels of COX-2 and 5-LOX in a time-dependent manner. Meanwhile, the level of p-ERK1/2 was increased, but the level of total ERK1/2 was unaffected, as demonstrated by western blot analysis (Figure 4C). The activation of ERK1/2 in response to exogenous AA was abolished in a dose-dependent manner by pretreatment of cells with PTX (Figure 4D), indo or NDGA (Figure 4E), suggesting that $\mathrm{Gi} / \mathrm{o}$ proteins, COX2 and 5-LOX act as intermediates in the AA-mediated activation of ERK1/2. Finally, a BrdU incorporation assay showed that exogenous AA promoted the growth of $\mathrm{L}-\mathrm{O} 2$ (or H7402) cells in a dose-dependent manner $(* P$ $<0.05$, Student's $t$-test; Figure 4F). Our data suggest that the AA metabolites released via a COX- and LOX-dependent mechanism, rather than AA itself, are responsible for the activation of ERK1/2. Thus, we conclude that AA metabolism contributes to the HBx-mediated promotion of proliferation of liver cells through p-ERK1/2.
Activation of ERK1/2 contributes to the upregulation of cPLA2, COX-2 and 5-LOX

The data above suggest that a link between AA metabolism and p-ERK1/2 could contribute to the cell growth mediated by HBx. Next, we determined whether $\mathrm{p}$ ERK1/2 contributes to the regulation of cPLA2, COX-2 and 5-LOX in L-O2-X and H7402-X cells. Reverse transcription-polymerase chain reaction (RT-PCR) showed that the expression levels of cPLA2, COX-2 and 5-LOX mRNA in L-O2-X (or H7402-X) cells were downregulated by treatment with $30 \mu \mathrm{M}$ PD98059 (an inhibitor of MEK1, upstream of ERK; Figure 5A). Western blot analysis showed that expression levels of cPLA2, COX-2 and 5-LOX proteins were also downregulated by PD98059 (Figure 5B). In addition, the amounts of PGE2 (a metabolite of COX-2) and LTB4 (a metabolite of 5-LOX) were decreased in the culture media from L-O2-X (or H7402$\mathrm{X}$ ) cells pretreated with $30 \mu \mathrm{M}$ PD98059 (PGE2: ${ }^{*} P=$ 0.029258 ; LTB4: ${ }^{*} P=0.047149$, vs untreated L-O2-X cells, Student's $t$-test; Figure $5 \mathrm{C}$ ). Our findings suggest that activation of ERK $1 / 2$ contributes to the upregulation of cPLA2, COX-2 and 5-LOX, and that ERK1/2 activation can be sustained in a positive feedback loop through the upregulation of COX-2 and 5-LOX.

\section{Discussion}

Hepatitis B virus infection is a major global health issue. In particular, the $\mathrm{HBx}$ protein has a multifaceted role in the development of $\mathrm{HCC}$, modulating signal transduction, cell-cycle progression, cell growth and apoptosis [4]. In this study, we have demonstrated that 
A

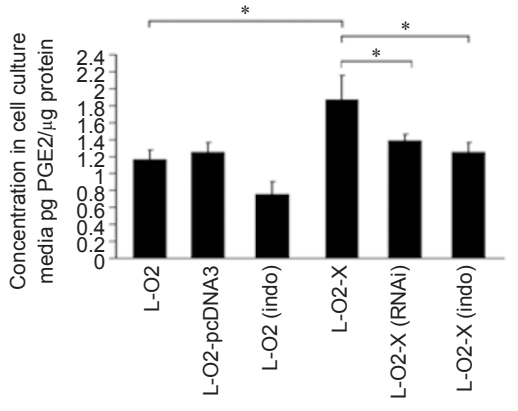

B

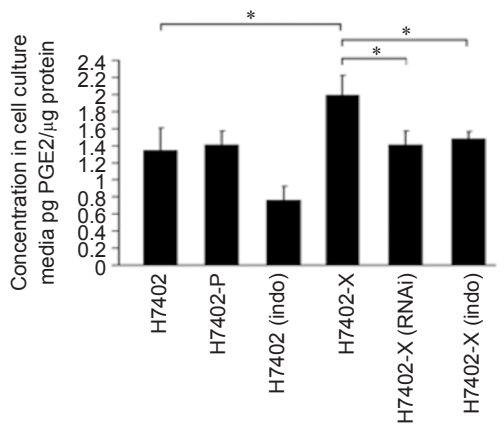

C
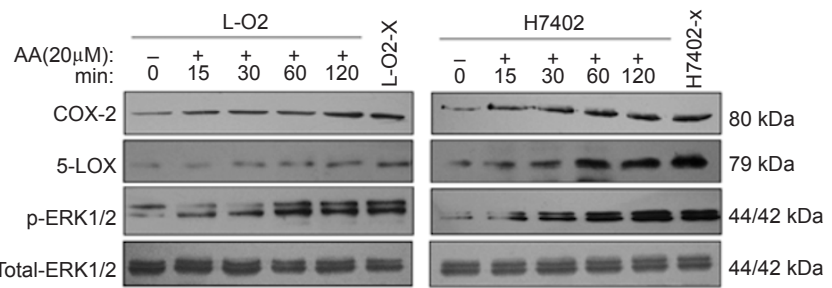
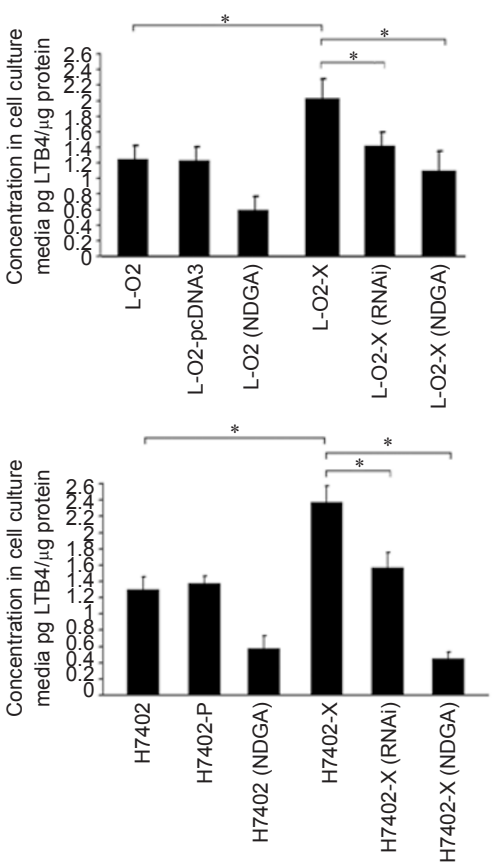

D

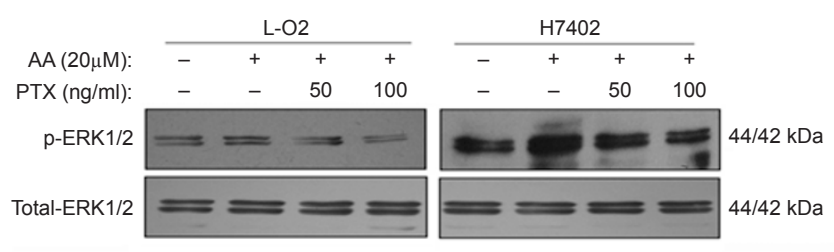

$E$

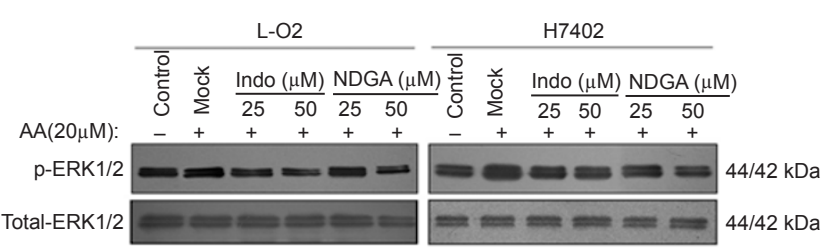

$\mathrm{F}$

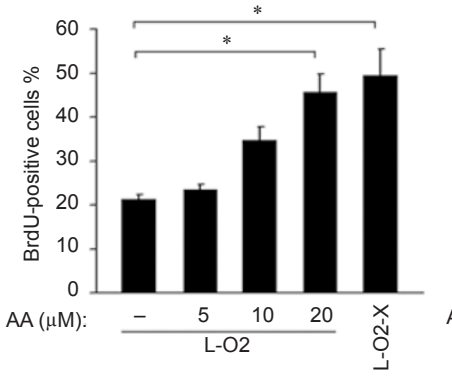

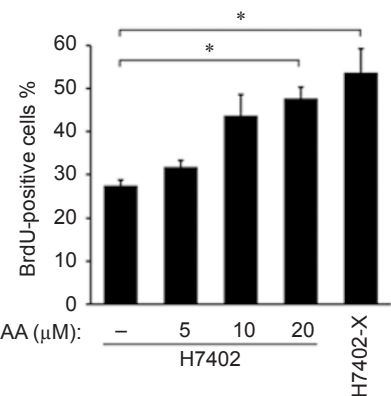

Figure 4 Released arachidonic acid metabolites (PGE2 and LTB4), not arachidonic acid itself, were responsible for the activation of ERK1/2 and cell growth. (A) ELISA showed that the level of PGE2 (a metabolite of COX-2) or LTB4 (a metabolite of 5-LOX) was higher in the conditioned media from L-O2-X cells relative to L-O2 cells $(P<0.05$, Student's $t$-test). Treatment with $50 \mu \mathrm{M}$ indo for $4 \mathrm{~h}$ decreased the amount of PGE2 and LTB4 released $(P<0.05$, Student's $t$-test). Meanwhile, the downregulation of HBx by RNAi abolished the increase of PGE2 and LTB4 $(P<0.05$, Student's $t$-test). The data revealed that HBx increased the levels of released PGE2 and LTB4. The data presented are from three independent experiments; error bars represent standard error. (B) Similar results to $\mathbf{A}$ are shown in H7402 and H7402-X cells. The data presented are from three independent experiments; error bars represent standard error. (C) The addition of $20 \mu \mathrm{M}$ arachidonic acid increased the expression of COX-2 and 5-LOX and activated ERK1/2 in L-O2 (or H7402) cells in a time-dependent manner, as shown by western blot analysis. (D) ERK1/2 activation in L-O2 (or H7402) cells was abolished by pretreatment with $50 \mathrm{ng} / \mathrm{ml}$ (or 100 $\mathrm{ng} / \mathrm{ml}$ ) PTX for $2 \mathrm{~h}$ in a dose-dependent manner, as shown by western blot analysis. (E) Indo and NDGA attenuated the activation of ERK ( $p$-ERK) in L-O2 (or H7402) cells pretreated with $20 \mu \mathrm{M}$ exogenous arachidonic acid (AA), as shown by western blot analysis. (F) BrdU incorporation assay showed that exogenous AA promoted the proliferation of L-O2 (or HH7402) cells in a dose-dependent manner $(P<0.05$, Student's $t$-test). The data presented are from three independent experiments; error bars represent standard error. 
A

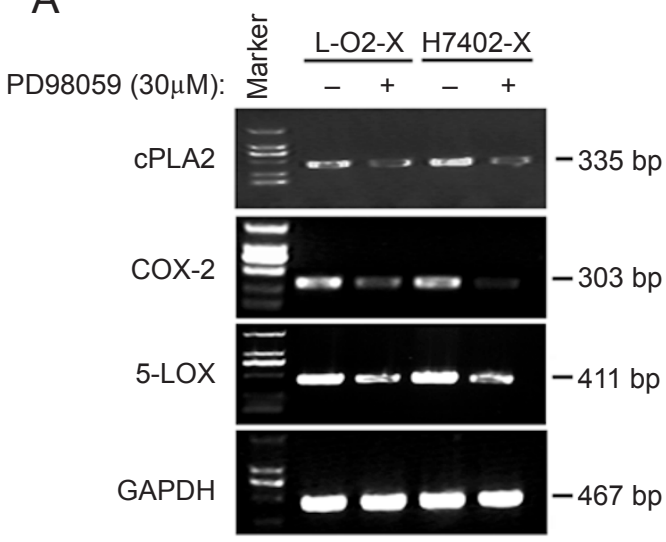

C
B
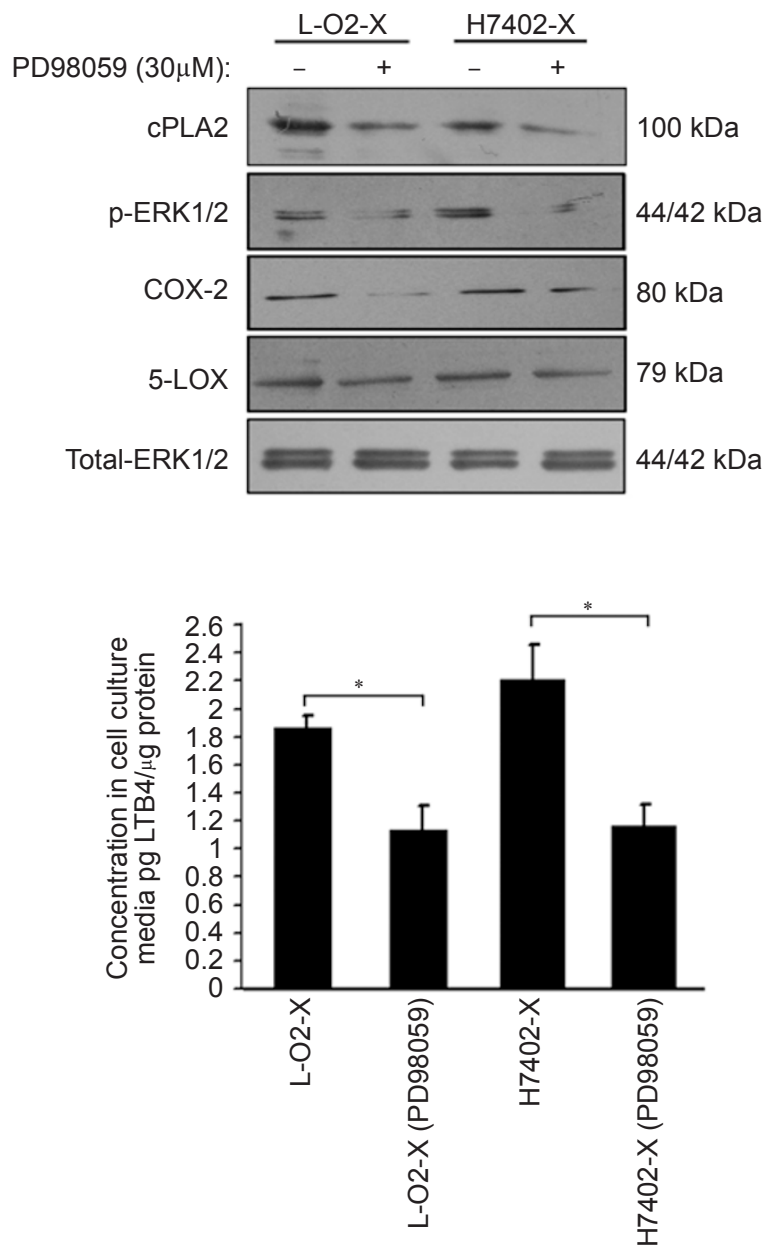

Figure 5 Activated ERK1/2 is responsible for upregulating the expression of CPLA2, COX and LOX. (A) RT-PCR analysis showed that $30 \mu \mathrm{M}$ PD98059 (an inhibitor of MEK1) reduced the expression of CPLA2, COX-2 and 5-LOX in L-O2-X (or $\mathrm{H} 7402-\mathrm{X}$ ) cells at the mRNA level. (B) Western blot analysis revealed that the protein levels of CPLA2, COX-2 and 5-LOX were also downregulated after treatment with $30 \mu \mathrm{M}$ PD98059. (C) ELISA results showed that the levels of PGE2 (a metabolite of COX-2) or LTB4 (a metabolite of 5-LOX) were decreased in the conditioned medium from L-O2-X (or H7402-X) cells pretreated with $30 \mu \mathrm{M}$ PD98059 for $4 \mathrm{~h}(P<0.05$, Student's $t$-test). The data presented are from three independent experiments; error bars represent standard error.

HBx enhances the proliferation of liver cells by a positive feedback loop involving AA metabolism by COX-2 and 5-LOX, ERK1/2 activation, released AA metabolites and $\mathrm{Gi} / \mathrm{o}$ proteins. Our conclusions are consistent with previous results in which $\mathrm{HBx}$ induced proliferation in cultured cells [27] and another study in which HBx expression induced cell-cycle progression within the milieu of the regenerating liver [28]. The results of our study oppose the conclusions of other studies that showed that transient transfection of HBx induced apoptosis and that HBx inhibited hepatocyte regeneration [29-31]. The reasons behind this apparent discrepancy need to be further investigated. In addition, these disparities highlight the need for physiologically relevant cell models to clarify the role of $\mathrm{HBx}$ in apoptosis and cell proliferation.

To better understand the physiological roles of $\mathrm{HBx}$, it is worthwhile to strive for a better understanding of the signaling pathways associated with $\mathrm{HBx}$-mediated cell growth. ERK-MAPK signaling has been clearly implicated in the regulation of liver cell proliferation [32, 33]. However, the molecular mechanism underlying the liver cell proliferation mediated by HBx remained unclear. In our previous study, we used a cDNA microarray to identify candidate target genes that were upregulated in L-O2-X and H7402-X cells [21, 34]. We found genes involved in MAPK and Wnt pathways and AA metabo- 
lism, suggesting that MAPK may play a crucial role in the HBx-mediated proliferation of liver cells.

The ERK signaling cascade is a central MAPK pathway that plays a role in the regulation of various cellular processes such as proliferation, differentiation and cellcycle progression [35-37]. In this study, we focused on the roles of $\mathrm{HBx}$ in promoting liver cell growth via $\mathrm{p}$ ERK $1 / 2$ and AA metabolite signaling pathways. Using the parallel L-O2-X and L-O2 (or L-O2-pcDNA3) cell lines, we observed that expression levels of COX-2 and 5 -LOX were higher in the L-O2-X cells (Figure 1). We also compared the levels of p-ERK1/2, p-p38 and p-JNK in L-O2-X and L-O2 (or L-O2-pcDNA3) cells. We found that the ERK signaling pathway was activated in L-O2-X cells (Figure 1). These data are consistent with the report that HBx can upregulate p-ERK1/2 in cancer tissues [7]. Our findings also suggested that AA metabolism might play an important role in the HBx-mediated proliferation of liver cells. Specifically, HBx may promote proliferation of liver cells by activating ERK $1 / 2$ and the p-ERK1/2 levels may be linked to AA metabolism.

The ERK signaling pathway is activated by a wide variety of receptors, including RTKs, GPCRs and ion channels [23]. It has been reported that $\mathrm{Gi} / \mathrm{o}$ proteins, which are known to affect a variety of cellular functions, activate $\mathrm{p}$-ERK $1 / 2$ and subsequent cell proliferation signals $[10,32]$. AA metabolites are also able to induce cell growth and have been strongly implicated in tumor development $[38,39]$. Exogenous AA and its lipid metabolites have been shown to induce ERK activation [40]. Several studies have demonstrated that specific inhibitors of COX and LOX reduce the incidence of development and metastasis of breast cancer tumors in animal models [41-44] and in humans [43]. Furthermore, COX2 inhibitors can inhibit the growth of $\mathrm{HBx}$-positive $\mathrm{HCC}$ cells [45]. The p-ERK1/2 cascade is the major signaling pathway for both COX-2 upregulation and PG synthesis [46]. Accumulating evidence suggests that 5-LOX has a vital role in the development and progression of human cancers and interacts with multiple intracellular signaling pathways that control cancer cell proliferation. 5-LOX inhibitors can block the proliferation of cancer cells [47]. To identify the signal transduction pathways associated with $\mathrm{HBx}$-mediated AA metabolism and activation of ERK1/2, we used inhibitors of COX, LOX and Gi/o proteins. Our data showed that the expression level of $\mathrm{p}$ ERK1/2 was decreased by the inhibitors of these proteins (indo, NDGA and PTX; Figure 2A). Therefore, our observations suggest that $\mathrm{COX}-2,5-\mathrm{LOX}$ and $\mathrm{Gi} / \mathrm{o}$ proteins are upstream activators of $\mathrm{p}$-ERK1/2.

We showed that both boiled and non-boiled conditioned media from L-O2-X cells were able to activate
ERK1/2 (Figure 2B, 2C and 2D). Together with the data above, this suggested that $\mathrm{HBX}$-mediated release of soluble AA metabolites is responsible for the activation of ERK1/2. Many studies have demonstrated that AA metabolites such as PGE2 and LTB4 have significant roles in cancer cell growth $[15,16]$, so we determined the levels of these in the conditioned media of L-O2-X cells. ELISA results showed that the levels of PGE2 and LTB4 were higher in the conditioned media of L-O2-X (or H7402-X) cells than in that of L-O2 (or H7402) cells (Figure 4A and 4B). This finding strongly suggests that these released AA metabolites are responsible for the activation of ERK1/2 in L-O2 (or H7402) cells. Moreover, we found that exogenous AA upregulated the levels of COX-2, 5-LOX and p-ERK1/2 (Figure 4C, 4D and 4E) in $\mathrm{L}-\mathrm{O} 2$ cells. The fact that the increase of $\mathrm{p}$-ERK $1 / 2$ was sensitive to the inhibition of COX and LOX suggests that the release of AA metabolites via COX and LOX activity, rather than AA itself, activates ERK1/2. Overall,

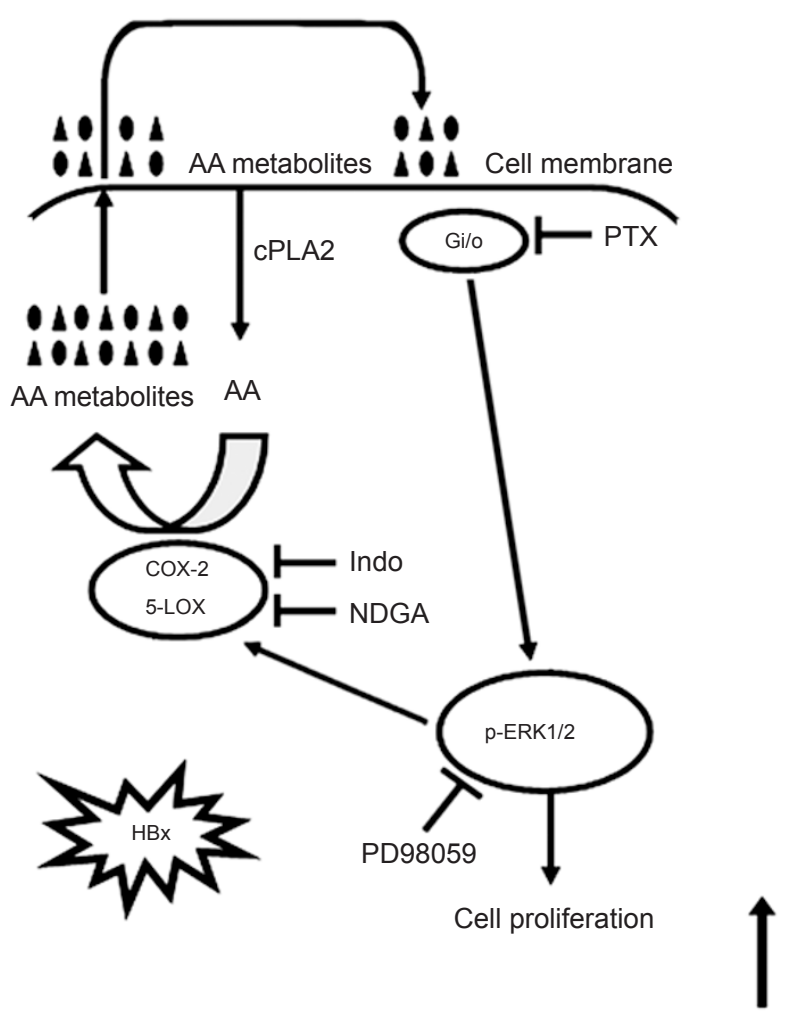

A model of positive cascade loop

Figure 6 A hypothetical model of the signaling pathway involved in the promotion and maintenance of $\mathrm{HBx}$-mediated proliferation of liver cells. HBx promotes and maintains cell growth by a positive cascade loop in which COX-2 and 5-LOX trigger the release of $\mathrm{AA}$ metabolites that in turn regulate $\mathrm{Gi} / \mathrm{o}$ proteins, $\mathrm{p}-\mathrm{ERK} 1 / 2$ and to complete the loop, COX-2 and 5-LOX. 
our findings indicate that $\mathrm{HBx}$ enhances the proliferation of liver cells through the activation of ERK1/2, with released AA metabolites acting as upstream activators. We hypothesized that activated ERK1/2 might upregulate the expression of COX-2 and 5-LOX to maintain the proliferation mediated by HBx and attempted to identify the effect of p-ERK1/2 on the regulation of cPLA2, COX-2 and 5-LOX. Interestingly, our results verified this hypothesis (Figure 5), thus providing new insight into the mechanism of cell proliferation that is mediated by HBx.

Our findings are summarized in a model in Figure 6. Constitutive expression of the HBx protein enhances and maintains the growth of liver cells by a positive feedback loop involving COX-2, 5-LOX, released AA metabolites, Gi/o proteins and $p$-ERK1/2. These findings enhance our understanding of the cell signaling pathways involved in HBV-related liver diseases and suggest potential therapies for these diseases, including perhaps the prevention of HCC.

\section{Materials and Methods}

\section{Cell culture}

L-O2 (a human immortalized liver cell line), L-O2-pcDNA3 (L-O2 stably transfected with the empty pcDNA3 plasmid) [48] and L-O2-X (L-O2 stably transfected with the pCMV-X plasmid, which contained the $X$ gene cloned from the HBV genome, subtype ayw) [48], H7402 (a human hepatoma cell line), H7402-P (H7402 stably transfected with the empty pcDNA3 plasmid), H7402-X (H7402 stably transfected with the pCMV-X plasmid) [34, 49] were maintained in RPMI Medium 1640 (Gibco, CA, USA) supplemented with heat-inactivated $10 \%$ fetal calf serum, $100 \mathrm{U} / \mathrm{ml}$ penicillin and $100 \mathrm{mg} / \mathrm{ml}$ streptomycin in a humidified atmosphere of $5 \% \mathrm{CO}_{2}$ and $95 \%$ air at $37{ }^{\circ} \mathrm{C}$.

\section{Treatment of cells with inhibitors}

L-O2, L-O2-pcDNA3 and L-O2-X (or H7402, H7402-P and $\mathrm{H} 7402-\mathrm{X}$ ) cells were cultured in six-well plates for $24 \mathrm{~h}$ as above, and then the cells were re-cultured in serum-free medium for 12 h. L-O2-X (or H7402-X) cells were treated with $50 \mathrm{ng} / \mathrm{ml}$ or 100 ng/ml PTX (an inhibitor of Gi/o proteins; List Biological Laboratories Inc., USA), $25 \mu \mathrm{M}$ or $50 \mu \mathrm{M}$ indo (an inhibitor of COX2; Sigma-Aldrich, USA) or $25 \mu \mathrm{M}$ or $50 \mu \mathrm{M}$ NDGA (an inhibitor of 5-LOX; Sigma-Aldrich) for 1 or $2 \mathrm{~h}$. L-O2 (or H7402 cells) were treated with $20 \mu \mathrm{M}$ AA for $15,30,60$ and $120 \mathrm{~min}$. L-O2 (or $\mathrm{H} 7402$ ) cells were treated with PTX, indo or NDGA at the concentrations defined previously, followed by treatment with $20 \mu \mathrm{M}$ AA for $2 \mathrm{~h}$. In addition, L-O2-X (or H7402-X) cells were treated with $30 \mu \mathrm{M}$ PD98059 (an inhibitor of MEK1; Sigma-Aldrich) for $4 \mathrm{~h}$. In the experiments that used siRNA, the L-O2-X (or H7402-X) cells were co-transfected with a $\mathrm{pSilencer-X}$ vector that produces siRNA targeting HBx mRNA or negative control siRNA [34].

The supernatants derived from the L-O2-X (or H7402-X) cell cultures, termed L-O2-X CM (or H7402-X CM), were harvested and stored at $-80{ }^{\circ} \mathrm{C}$ until used as conditioned media for cell treatment. L-O2-X (or H7402-X) cells were pretreated by the inhibi- tors, $50 \mu \mathrm{M}$ indo or $50 \mu \mathrm{M}$ NDGA, for $2 \mathrm{~h}$ and were subsequently washed three times with fresh media and re-cultured in fresh media for $48 \mathrm{~h}$. The supernatants, termed L-O2-X CM (indo) or L-O2-X CM (NDGA) or H7402-X CM (indo or NDGA), were harvested and stored until used as conditioned media. L-O2 (or H7402) cells were cultured for $48 \mathrm{~h}$, followed by treatment with $50 \%$ or $100 \%$ L-O2-X CM (or H7402-X CM), boiled $50 \%$ or $100 \%$ L-O2-X CM (or H7402-X CM), termed L-O2-X BCM (or H7402-X BCM) and $50 \%$ or $100 \%$ L-O2-X CM (indo or NDGA) (or H7402-X CM (indo or NDGA)) for $12 \mathrm{~h}$. The cells cultured with conditioned media were subjected to western blot analysis, luciferase reporter gene assays, flow cytometry analysis, ELISA and RT-PCR.

In addition, the cell culture supernatants of L-O2 cells, termed $\mathrm{L}-\mathrm{O} 2 \mathrm{CM}$, were harvested and stored at $-80{ }^{\circ} \mathrm{C}$ until used as conditioned media. L-O2 cells were pretreated with $50 \%$ or $100 \%$ $\mathrm{L}-\mathrm{O} 2 \mathrm{CM}$ for $12 \mathrm{~h}$ and $50 \mu \mathrm{M}$ indo and $50 \mu \mathrm{M}$ NDGA for $2 \mathrm{~h}$ before serum-free culture. The levels of p-ERK1/2 in the treated L-O2 cells were examined by western blot analysis.

\section{Nitro blue tertrazolium assay}

To examine the cytotoxicity of the tested inhibitors, L-O2 and $\mathrm{L}-\mathrm{O} 2-\mathrm{X}$ cells were cultured in 96-well plates for $24 \mathrm{~h}$ as above, after which the cells were re-cultured in serum-free medium for $12 \mathrm{~h}$. L-O2 and L-O2-X cells were treated for $2 \mathrm{~h}$ with PTX, indo, NDGA or PD98059 at the concentrations defined previously. Cytotoxicity was analyzed by the reduction of NBT (Sigma-Aldrich). Briefly, $0.75 \mu \mathrm{M}$ NBT was added to the treated cells, which were then incubated at $37{ }^{\circ} \mathrm{C}$ for $1 \mathrm{~h}$. Then, the absorbance was read with an ELISA reader system (Labsystem Multiskan Ascent) at $560 \mathrm{~nm}$. The conditions of the NBT assay were as described by Wei et al. [50].

\section{Western blot analysis}

The cells treated by the protocols above were washed three times with ice-cold PBS and total protein was extracted directly in lysis buffer. The experiment was performed as previously reported [34]. The primary antibodies used were anti-p-ERK1/2, antitotal-ERK1/2, anti-phosphorylated-JNK (p-JNK) (Cell Signaling Technology, USA), anti-cPLA2, anti-phosphorylated p38 (p-p38), anti- $\beta$-actin (Sigma-Aldrich), anti-HBx (Abcom, Cambridge, UK), anti-COX-2 and anti-5-LOX (NeoMarkers, USA). The membranes were washed three times in PBS with $0.1 \%$ Tween 20 and incubated for $1 \mathrm{~h}$ with secondary antibody (peroxidase-conjugated antirabbit or anti-mouse $\operatorname{IgG}$ ). The membranes were then washed three times, and the bands were visualized using ECL reagent (Amersham Pharmacia Biotech, Milan, Italy).

\section{Luciferase reporter gene assay}

Cells were cultured in 24-well plates and transfected with reporter constructs $(0.3 \mu \mathrm{g}$ per well) using Lipofectamine 2000 reagent. The luciferase reporters used were as follows: pGL3NF- $\kappa$ B, pGL3-AP-1, pGL3-basic, pGL3-control (0.3 $\mu$ g per well) and the renilla luciferase reporter vector, $\mathrm{pRL}-\mathrm{TK}$. The luciferase reporter assay was performed according to the dual-luciferase reporter assay system (Promega) in L-O2, L-O2-pcDNA3 and L-O2-X (or H7402, H7402-P and H7402-X) cells using the above vectors and the pSilencer-X plasmid [34]. Luciferase activity was measured using FB12 Single Tube luminometer (Berthold Detection Systems GmbH, Germany). NF- $\mathrm{BB}$ or AP-1 promoter activity 
was analyzed by detecting firefly luciferase activity and normalizing to renilla luciferase activity in each well (each assay was performed in triplicate) as previously described [48].

\section{BrdU incorporation assay}

The BrdU (Sigma, St. Louis, MO, USA) incorporation assay is used to measure DNA synthesis, a sign of cell proliferation [51]. L-O2 and L-O2-X (or H7402 and H7402-X) cells were seeded in 24-well plates for $12 \mathrm{~h}$ and were serum starved in the defined media overnight. L-O2-X (or H7402-X) cells were treated with 100 ng/ml PTX for $2 \mathrm{~h}$. L-O2 (or H7402) cells were treated with L-O2X CM (or H7402-X CM) or L-O2-X CM (indo) (or H7402-X CM (indo)) for $12 \mathrm{~h}$. L-O2 (or H7402) cells were treated with 5, 10, 20 $\mu \mathrm{M}$ AA for $2 \mathrm{~h}$. The BrdU incorporation assay was performed as previously described [52].

\section{MTT assay}

For the MTT (Sigma) assay, cells were incubated in 96-well plates at a density of $10^{3}$ cells per well. After $48 \mathrm{~h}, 20 \mu \mathrm{lof} 5 \mathrm{mg} /$ $\mathrm{ml}$ MTT was added to each well. After incubation at $37^{\circ} \mathrm{C}$ for $4 \mathrm{~h}$, the supernatants were removed carefully. Then $200 \mu$ of dimethyl sulfoxide (Sigma) was added to each well and the wells were thoroughly mixed for $10 \mathrm{~min}$. The absorbance value (OD) at $490 \mathrm{~nm}$ of each well was measured using an ELISA reader system (Labsystem Multiskan Ascent). All experiments were performed in triplicate.

\section{Flow cytometry analysis}

The treated cells described above $\left(1 \times 10^{6}\right.$ cells $)$ were harvested by trypsinization and washed twice with PBS. After centrifugation, the cells were resuspended in $2 \mathrm{ml}$ of $70 \%$ ethanol at $4{ }^{\circ} \mathrm{C}$ overnight. After rinsing twice with $\mathrm{PBS}$, the fixed cells were resuspended in PBS containing $50 \mu \mathrm{g} / \mathrm{ml}$ RNaseA (Sigma) and incubated at $37{ }^{\circ} \mathrm{C}$ for $30 \mathrm{~min}$. Propidium iodide solution was added at a concentration of $50 \mu \mathrm{g} / \mathrm{ml}$. The stained cells were passed through a nylon-mesh sieve to remove cell clumps and were then analyzed by a FACScan flow cytometer (Becton Dickinson, San Jose, CA, USA); the results were analyzed using CellQuest software (Becton Dickinson). The cell PI was calculated as the sum of the S and G2/ $\mathrm{M}$ phase cells, expressed as a fraction of the total cell population $(\mathrm{PI}=((\mathrm{S}+\mathrm{G} 2 / \mathrm{M}) /(\mathrm{G} 0 / \mathrm{G} 1+\mathrm{S}+\mathrm{G} 2 / \mathrm{M})) \times 100)[53]$. The flow cytometry experiment was repeated three times.

\section{Enzyme-linked immunosorbent assay}

The amounts of PGE2 (a metabolite of COX-2) and LTB4 (a metabolite of 5-LOX) in $100 \mu \mathrm{l}$ aliquots of media were determined using a commercially available assay (human PGE2 and LTB4 ELISA kit; ADL, USA) according to the manufacturer's instruction. Plates were read at $450 \mathrm{~nm}$ using an ELISA reader system (Labsystem Multiskan Ascent) and the concentrations of PGE2 and LTB4 were calculated from the standard curve. The concentrations of PGE2 and LTB4 were normalized to total protein. The protein concentrations in these extracts were determined using a standard protein assay (Bio-Rad Laboratories Inc., Hercules, CA, USA).

\section{Reverse transcription polymerase chain reaction}

Extraction of total RNA and reverse transcription were carried out as previously described [23]. The primers used for RT-PCR are as follows - cPLA2 forward: 5'-TCT ACT ACG AGG GCG ACC
AGG-3', reverse: 5'-AGA TGG CCA CAC TGT TCG GAA-3';

COX-2 forward: 5'-TTC AAA TGA GAT TGT GGC AAA ATT GCT-3', reverse: 5'-GAT CAT CTC TGC CTG AGT ATC TT-3'; 5-LOX forward: 5'-ATC AGG ACG TTC ACG GCC GAG G-3', reverse: 5'-CCA GGA ACA GCT CGT TTT CCT G-3' and GAPDH forward: 5'-CAT CAC CAT CTT CCA GGA GCG-3', GAPDH reverse: 5'-TGA CCT TGC CCA CAG CCT TG - $3^{\prime}$. The PCR conditions were as follows: $94{ }^{\circ} \mathrm{C}$ for $10 \mathrm{~min}$, followed by 35 cycles of amplification $\left(94{ }^{\circ} \mathrm{C}\right.$ for $30 \mathrm{~s}, 50{ }^{\circ} \mathrm{C}$ for $45 \mathrm{~s}, 72{ }^{\circ} \mathrm{C}$ for $45 \mathrm{~s}$ ), and a final extension at $72^{\circ} \mathrm{C}$ for $10 \mathrm{~min}$.

\section{Statistical analysis}

Data were analyzed using SPSS software version 13.0 (Chicago, IL, USA). Statistical significance was assessed by comparing the mean values $( \pm \mathrm{SD})$ using a Student's $t$-test.

\section{Acknowledgments}

This work was supported by grants from the National Basic Research Program of China (973 Program, Nos. 2007CB914804, 2007CB914802, 2009CB521702) and the National Natural Scientific Foundation of China (No. 30670959).

\section{References}

1 Zanetti AR, Van Damme P, Shouval D. The global impact of vaccination against hepatitis $\mathrm{B}$ : a historical overview. Vaccine 2008; 26:6266-6273.

2 Zhang X, Zhang W, Ye L. Pathogenesis of hepatitis B virus infection. Future Virol 2006; 1:637-647.

3 Arbuthnot P, Capovilla A, Kew M. Putative role of hepatitis B virus $\mathrm{X}$ protein in hepatocarcinogenesis: effects on apoptosis, DNA repair, mitogen-activated protein kinase and JAK/STAT pathways. J Gastroenterol Hepatol 2000; 15:357-368.

4 Tang H, Oishi N, Kaneko S, Murakami S. Molecular functions and biological roles of hepatitis B virus X protein. Cancer Sci 2006; 97:977-983.

5 Zhang X, Zhang H, Ye L. Effects of hepatitis B virus X protein on the development of liver cancer. J Lab Clin Med 2006; 147:58-66.

6 Lee YI, Kang-Park S, Do SI, Lee YI. The hepatitis B virus-X protein activates a phosphatidylinositol 3-kinase-dependent survival signaling cascade. J Biol Chem 2001; 276:1696916977.

7 Chung TW, Lee YC, Kim CH. Hepatitis B viral HBx induces matrix metalloproteinase-9 gene expression through activation of ERK and PI-3K/AKT pathways: involvement of invasive potential. FASEB J 2004; 18:1123-1125.

8 Lee SG, Rho HM. Transcriptional repression of the human p53 gene by hepatitis B viral X protein. Oncogene 2000; 19:468-471.

9 Roux PP, Blenis J. ERK and p38 MAPK-activated protein kinases: a family of protein kinases with diverse biological functions. Microbiol Mol Biol Rev 2004; 68:320-344.

10 Lawrence MC, Jivan A, Shao C, et al. The roles of MAPKs in disease. Cell Res 2008; 18:436-442.

11 Nijhara R, Jana SS, Goswami SK, et al. Sustained activation of mitogen-activated protein kinases and activator protein 1 
by the hepatitis B virus $\mathrm{X}$ protein in mouse hepatocytes in vivo. J Virol 2001; 75:10348-10358.

12 Kolch W. Meaningful relationships: the regulation of the Ras/ Raf/MEK/ERK pathway by protein interactions. Biochem $J$ 2000; 351:289-305.

13 Chen KH, Weng MS, Lin JK. Tangeretin suppresses IL-1betainduced cyclooxygenase (COX)-2 expression through inhibition of p38 MAPK, JNK, and AKT activation in human lung carcinoma cells. Biochem Pharmacol 2007; 73:215-227

14 Ouyang X, Jessen WJ, Al-Ahmadie H, et al. Activator protein-1 transcription factors are associated with progression and recurrence of prostate cancer. Cancer Res 2008; 68:21322144.

15 Pidgeon GP, Lysaght J, Krishnamoorthy S, et al. Lipoxygenase metabolism: roles in tumor progression and survival. Cancer Metastasis Rev 2007; 26:503-524.

16 Hammamieh R, Sumaida D, Zhang X, Das R, Jett M. Control of the growth of human breast cancer cells in culture by manipulation of arachidonate metabolism. BMC Cancer 2007; 7:138.

17 Canali R, Comitato R, Schonlau F, Virgili F. The anti-inflammatory pharmacology of Pycnogenol((R)) in humans involves COX-2 and 5-LOX mRNA expression in leukocytes. Int Immunopharmacol 2009; 9:1145-1149.

18 Covey TM, Edes K, Fitzpatrick FA. Akt activation by arachidonic acid metabolism occurs via oxidation and inactivation of PTEN tumor suppressor. Oncogene 2007; 26:5784-5792.

19 Lara-Pezzi E, Gomez-Gaviro MV, Galvez BG, et al. The hepatitis $\mathrm{B}$ virus $\mathrm{X}$ protein promotes tumor cell invasion by inducing membrane-type matrix metalloproteinase- 1 and cyclooxygenase-2 expression. J Clin Invest 2002; 110:18311838.

20 Cheng AS, Chan HL, Leung WK, et al. Expression of HBx and COX-2 in chronic hepatitis $\mathrm{B}$, cirrhosis and hepatocellular carcinoma: implication of $\mathrm{HBx}$ in upregulation of COX-2. Mod Pathol 2004; 17:1169-1179.

21 Zhang WY, Xu FQ, Shan CL, Xiang R, Ye LH, Zhang XD. Gene expression profiles of human liver cells mediated by hepatitis B virus X protein. Acta Pharmacol Sin 2009; 30:424-434.

22 Zhang WY, Cai N, Ye LH, Zhang XD. Transformation of human liver L-O2 cells mediated by stable HBx transfection. Acta Pharmacol Sin 2009; 30:1153-1161.

23 Qin X, Zhang H, Zhou X, et al. Proliferation and migration mediated by Dkk-1/Wnt/beta-catenin cascade in a model of hepatocellular carcinoma cells. Transl Res 2007; 150:281294.

24 Cowan KJ, Storey KB. Mitogen-activated protein kinases: new signaling pathways functioning in cellular responses to environmental stress. J Exp Biol 2003; 206:1107-1115.

25 Heo KS, Kim DU, Kim L, et al. Activation of PKCbeta(II) and PKCtheta is essential for LDL-induced cell proliferation of human aortic smooth muscle cells via Gi-mediated Erk1/2 activation and Egr-1 upregulation. Biochem Biophys Res Commun 2008; 368:126-131.

26 Jun DJ, Lee JH, Choi BH, et al. Sphingosine-1-phosphate modulates both lipolysis and leptin production in differentiated rat white adipocytes. Endocrinology 2006; 147:58355844.
27 Zhang JL, Zhao WG, Wu KL, et al. Human hepatitis B virus $\mathrm{X}$ protein promotes cell proliferation and inhibits cell apoptosis through interacting with a serine protease Hepsin. Arch Virol 2005; 150:721-741.

28 Hodgson AJ, Keasler VV, Slagle BL. Premature cell cycle entry induced by hepatitis $\mathrm{B}$ virus regulatory $\mathrm{HBx}$ protein during compensatory liver regeneration. Cancer Res 2008; 68:10341-10348.

29 Chen HY, Tang NH, Lin N, Chen ZX, Wang XZ. Hepatitis B virus $\mathrm{X}$ protein induces apoptosis and cell cycle deregulation through interfering with DNA repair and checkpoint responses. Hepatol Res 2008; 38:174-182.

30 Tralhao JG, Roudier J, Morosan S, et al. Paracrine in vivo inhibitory effects of hepatitis $\mathrm{B}$ virus $\mathrm{X}$ protein $(\mathrm{HBx})$ on liver cell proliferation: an alternative mechanism of $\mathrm{HBx}$-related pathogenesis. Proc Natl Acad Sci USA 2002; 99:6991-6996.

31 Miao J, Chen GG, Chun SY, Lai PP. Hepatitis B virus X protein induces apoptosis in hepatoma cells through inhibiting Bcl-xL expression. Cancer Lett 2006; 236:115-124.

32 Kim IS, Ryang YS, Kim YS, et al. Leukotactin-1-induced ERK activation is mediated via $\mathrm{Gi} / \mathrm{Go}$ protein/PLC/PKC delta/Ras cascades in HOS cells. Life Sci 2003; 73:447-459.

33 Viala E, Pouyssegur J. Regulation of tumor cell motility by ERK mitogen-activated protein kinases. Ann NY Acad Sci 2004; 1030:208-218.

34 Zhang X, Dong N, Yin L, et al. Hepatitis B virus X protein upregulates survivin expression in hepatoma tissues. $J$ Med Virol 2005; 77:374-381.

35 Yoon S, Seger R. The extracellular signal-regulated kinase: multiple substrates regulate diverse cellular functions. Growth Factors 2006; 24:21-44.

36 Sharma GD, He J, Bazan HE. p38 and ERK1/2 coordinate cellular migration and proliferation in epithelial wound healing: evidence of cross-talk activation between MAP kinase cascades. J Biol Chem 2003; 278:21989-21997.

37 Segarra J, Balenci L, Drenth T, Maina F, Lamballe F. Combined signaling through ERK, PI3K/AKT, and RAC1/p38 is required for met-triggered cortical neuron migration. $J$ Biol Chem 2006; 281:4771-4778.

38 Fulton AM, Ma X, Kundu N. Targeting prostaglandin E EP receptors to inhibit metastasis. Cancer Res 2006; 66:97949797.

39 Nithipatikom K, Isbell MA, Lindholm PF, et al. Requirement of cyclooxygenase-2 expression and prostaglandins for human prostate cancer cell invasion. Clin Exp Metastasis 2002; 19:593-601.

40 Alexander LD, Cui XL, Falck JR, Douglas JG. Arachidonic acid directly activates members of the mitogen-activated protein kinase superfamily in rabbit proximal tubule cells. Kidney Int 2001; 59:2039-2053.

41 Brown MD, Hart CA, Gazi E, Bagley S, Clarke NW. Promotion of prostatic metastatic migration towards human bone marrow stoma by Omega 6 and its inhibition by Omega 3 PUFAs. Br J Cancer 2006; 94:842-853.

42 Kundu N, Walser TC, Ma X, Fulton AM. Cyclooxygenase inhibitors modulate NK activities that control metastatic disease. Cancer Immunol Immunother 2005; 54:981-987.

43 Romano M, Claria J. Cyclooxygenase-2 and 5-lipoxygenase converging functions on cell proliferation and tumor an- 
giogenesis: implications for cancer therapy. FASEB J 2003; 17:1986-1995.

44 Howe LR, Dannenberg AJ. A role for cyclooxygenase-2 inhibitors in the prevention and treatment of cancer. Semin Oncol 2002; 29:111-119.

45 Xie H, Gao L, Chai N, et al. Potent cell growth inhibitory effects in hepatitis B virus X protein positive hepatocellular carcinoma cells by the selective cyclooxygenase-2 inhibitor celecoxib. Mol Carcinog 2009; 48:56-65.

46 Martinez-Gonzalez J, Escudero I, Badimon L. Simvastatin potenciates PGI(2) release induced by HDL in human VSMC: effect on Cox-2 up-regulation and MAPK signalling pathways activated by HDL. Atherosclerosis 2004; 174:305-313.

47 Ding XZ, Hennig R, Adrian TE. Lipoxygenase and cyclooxygenase metabolism: new insights in treatment and chemoprevention of pancreatic cancer. Mol Cancer 2003; 2:10.

48 Zhang H, Shan CL, Li N, et al. Identification of a natural mutant of HBV X protein truncated 27 amino acids at the $\mathrm{COOH}$ terminal and its effect on liver cell proliferation. Acta Phar- macol Sin 2008; 29:473-480.

49 Ye L, Dong N, Wang Q, et al. Progressive changes in hepatoma cells stably transfected with hepatitis $\mathrm{B}$ virus $\mathrm{X}$ gene. Intervirology 2008; 51:50-58.

50 Wei Y, Chen L, Chen J, He RQ. Rapid glycation with D-ribose induces globular amyloid-like aggregations of BSA with high cytotoxicity to SH-SY5Y cells. BMC Cell Biol 2009; 10:10.

51 Lengronne A, Pasero P, Bensimon A, Schwob E. Monitoring $\mathrm{S}$ phase progression globally and locally using BrdU incorporation in TK (+) yeast strains. Nucleic Acids Res 2001; 29:1433-1442.

52 Wang J, Shen WH, Jin YJ, Brandt-Rauf PW, Yin Y. A molecular link between E2F-1 and the MAPK cascade. J Biol Chem 2007; 282:18521-18531.

53 Wang FZ, Sha L, Zhang WY, et al. Involvement of hepatitis B $\mathrm{X}$-interacting protein (HBXIP) in proliferation regulation of cells. Acta Pharmacol Sin 2007; 28:431-438.

(Supplementary information is linked to the online version of the paper on the Cell Research website.) 